\title{
MODELE OBLICZENIOWE POŚREDNICH ŻEBER POPRZECZNYCH BLACHOWNIC W STANIE NADKRYTYCZNYM ŚRODNIKA
}

\begin{abstract}
W artykule przedstawiono podstawowe teorie nośności nadkrytycznej blachownic stalowych mające zastosowanie we współczesnych normach projektowania. Opisano rozbudowaną metodykę wymiarowania pośrednich żeber usztywniających blachownice zawartą w normie PN-EN 1993-1-5 [11] odnosząc się do bazowych teorii nośności nadkrytycznej. Wskazano niekonsekwencję i niespójność w przepisach normy, których efektem może być znaczne, nawet kilkukrotne [15], przeszacowanie wartości sił podłużnych działających na żebro w nadkrytycznym stadium pracy blachownicy.
\end{abstract}

Słowa kluczowe: poprzeczne żebra pośrednie, rezerwa nośności nadkrytycznej, stateczność środnika ścinanego

\section{Wprowadzenie}

Proces projektowania żeber poprzecznych blachownic ewoluował wraz z rozwojem teorii stateczności płyt i powłok metalowych. Pierwotnie, przy wymiarowaniu blachownic pracujących w stanie dokrytycznym, żebra pośrednie służyły jedynie zwiększeniu naprężeń krytycznych płyt środnika i pasów oraz zmniejszały podatność poprzecznego przekroju blachownicy na deformacje typu dystorsyjnego. Projektowanie przekroju poprzecznego żeber przeprowadzano wykorzystując formuły oparte na liniowej teorii stateczności płyt użebrowanych. Należy jednak zaznaczyć, że utrata stateczności lokalnej ścianek blachownicy nie stanowi kresu jej nośności, niezależnie od tego czy przyczyną jest działanie naprężeń normalnych, stycznych czy ich kombinacja. Nowo powstała po utracie stateczności konfiguracja geometryczno-obciążeniowa jest stanem równowagi stabilnej w którym, pomimo redukcji sztywności giętnej

\footnotetext{
${ }^{1}$ Autor do korespondencji: Krzysztof Kuchta, Politechnika Krakowska, 31-155 Kraków, ul. Warszawska 24, kkuchta@pk.edu.pl

2 Izabela Tylek, Politechnika Krakowska, 31-155 Kraków, ul. Warszawska 24, itylek@pk.edu.pl
} 
przekroju, wzrostowi przemieszczeń towarzyszy wzrost obciążenia. Stan ten tworzy tzw. nadkrytyczną rezerwę nośności, którą można wykorzystać w celu zmniejszenia masy profilu blachownicy.

Naprężenia krytyczne sprężystej utraty stateczności środnika aż do lat 50-tych ubiegłego wieku stanowiły podstawę wymiarowania blachownic, mimo iż już w 1886 r. J. M. Wilson opisał mechanizm nadkrytycznej pracy blachownic mostów kolejowych [5].

Geneza nowych metod projektowania blachownic ma swój początek w rozwoju techniki lotniczej, silnie zintensyfikowanym podczas I Wojny Światowej. Przejście od drewniano-tekstylnej do w pełni metalowej konstrukcji kadłuba i płatów nośnych samolotów oraz opracowanie skrzynkowej konstrukcji skrzydła skośnego ponaddźwiękowego samolotu turboodrzutowego pod koniec II Wojny Światowej nie byłoby możliwe bez opracowania teorii, która skutecznie opisywałaby zachowanie się cienkich metalowych płyt i powłok w stanach nadkrytycznych. Ze względu na ogromne znaczenie militarne wiele, pionierskich w tej dziedzinie badań naukowców niemieckich, objętych było ścisłą tajemnicą do czasu zakończenia działań wojennych [8]. Pierwsze, mające praktyczne znaczenie, modele obliczeniowe umożliwiające wykorzystanie nadkrytycznych rezerw nośności w blachownicach stalowych zostały opracowane dopiero pod koniec lat 50-tych ubiegłego wieku; od tego czasu datuje się późniejszy intensywny rozwój tej dziedziny badań.

Wraz z rozwojem techniki komputerowej i numerycznych metod obliczeniowych możliwe stało się badanie zachowania blachownic w stanach nadkrytycznych przy odrzuceniu założenia modelowego o pierwotnej geometrycznie i strukturalnie idealnej blachownicy. Umożliwiło to stopniowe wprowadzenie do inżynierskich modeli obliczeniowych początkowych imperfekcji geometrycznych, które są nieuniknioną konsekwencją procesów wytwarzania stalowych konstrukcji budowlanych. Wykorzystanie nadkrytycznej rezerwy nośności blachownicy nie jest w pełni możliwe bez udziału poprzecznych żeber usztywniających, które po przejściu z dokrytycznej do nadkrytycznej fazy pracy blachownicy zaczynają pełnić nową, odmienną rolę, stając się elementem ustroju nośnego blachownicy. Zastosowanie żeber poprzecznych oraz racjonalny dobór ich przekroju poprzecznego może w istotnym stopniu zwiększyć nośność blachownicy w fazie pracy nadkrytycznej.

Celem artykułu jest przedstawienie w możliwie zwartej i syntetycznej formie teorii oraz metod projektowania pośrednich żeber poprzecznych w taki sposób, aby można było poddać krytycznej ocenie zasady wymiarowania tych elementów zawarte w polskich normach PN-B 3200:1990 [10] oraz PN-EN 1993$1-5[11]$. 


\section{Nośność graniczna środników blachownic}

Pierwsze, przydatne dla praktyki inżynierskiej zasady wymiarowania blachownic $\mathrm{w}$ fazie nadkrytycznej powstały dzięki pracom badawczym Baslera $[1,2]$ oraz Baslera i Thürlimanna [3], które rozpoczęto pod koniec lat 50-tych ubiegłego wieku w Lehigh University w USA. Rozwój badań był kontynuowany w wielu ośrodkach naukowych świata. Obszerne zestawienie opracowanych metod analizy stanu nadkrytycznego zawiera m.in. monografia Galambosa [5].

W Polsce, do czasu ustanowienia normy PN-EN 1993-1-5 [11], projektowanie blachownic przy wykorzystaniu rezerwy nadkrytycznej paneli ścinanych i zginanych nie było możliwe na mocy przepisów normowych [10], mimo dopuszczalności wykorzystania nadkrytycznej rezerwy nośności przy działaniu naprężeń normalnych. Lukę tą wypełniał tzw. „model krakowski” opracowany w ramach programu badań blachownic dwuteowych i skrzynkowych zrealizowanego przez Siepaka i Piekarczyka $[9,13,14]$ na Politechnice Krakowskiej.

Analizując pracę smukłej blachownicy zginanej o geometrii i strukturze pozbawionej imperfekcji można wyróżnić trzy podstawowe fazy pracy (rys. 1).

a)

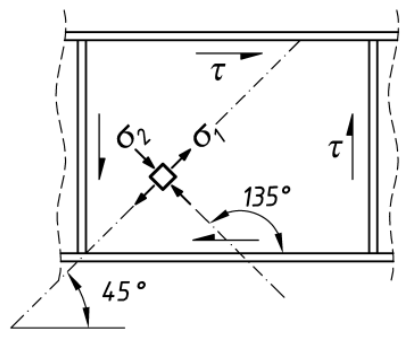

b)

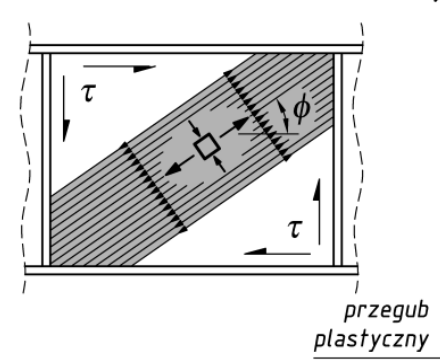

c)

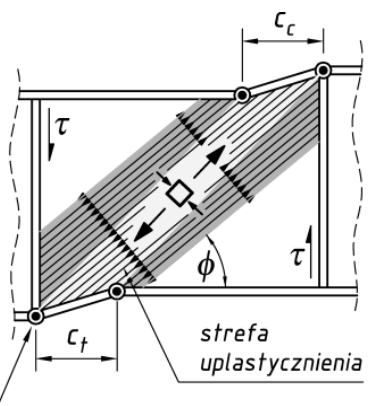

Rys. 1. Fazy pracy segmentu blachownicy poddanej działaniu sił poprzecznych: a) stan dokrytyczny (faza pracy belkowej), b) stan nadkrytyczny (faza pracy pola ciągnień), c) stan graniczny nośności (faza pracy ramowej)

Fig. 1. Behaviour of girder panel under shear force action: a) pre-buckling state (beam action phase), b) post-buckling state (tension field action phase), c) ultimate limit state (frame action phase)

$\mathrm{W}$ fazie dokrytycznej naprężenia główne $\sigma_{1}$ i $\sigma_{2}$ w panelu środnika są sobie równe, a kąt $\phi$ pochylenia stycznej do trajektorii naprężeń względem osi belki jest równy $45^{\circ}$. Przy dalszym wzroście obciążenia dochodzi do sprężystej utraty stateczności panelu środnika, czego obrazem jest uformowanie się charakterystycznego pola przemieszczeń zwanego polem ciągnień, zawierającego główne pole ciągnień i boczne pola ciągnień (rys. 2). 
a)

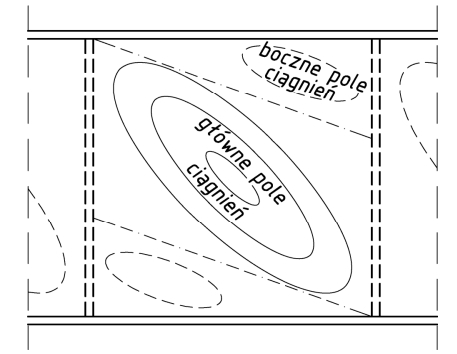

b)

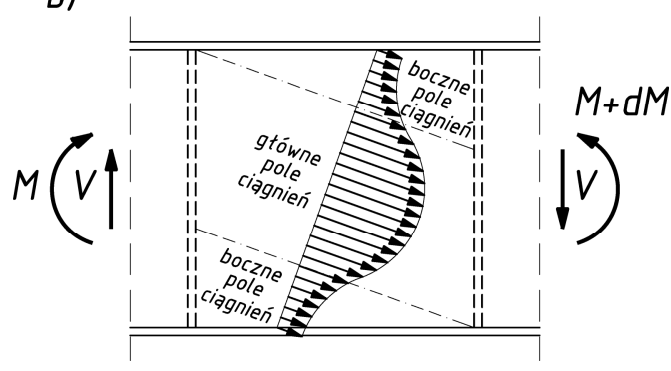

Rys. 2. Pole ciągnień w panelu środnika blachownicy: a) warstwice przemieszczeń prostopadłych do płaszczyzny środnika [9], b) rozkład naprężeń normalnych pola ciągnień

Fig. 2. Tension field in web panel of a girder: a) contour lines of displacements perpendicular to the web plane [9], b) distribution of tension field normal stresses

Naprężenia główne ściskające nie mogą wzrastać ponad wartość naprężeń krytycznych, dalszy przyrost obciążenia powoduje zatem zwiększanie się naprężeń rozciągających, które ponadto spełniają dodatkową rolę stabilizującą panel co, mimo stosunkowo dużych smukłości płyt środnika, jest przyczyną stosunkowo niewielkiej wrażliwości na początkowe imperfekcje geometryczne. Faza pracy pola ciągnień często porównywana jest do pracy kratownicy o pasach równoległych z jednoskośnym wykratowaniem słupkowo-krzyżulcowym, tzw. kratownica Pratta, w której rozciągane pasma głównego pola ciągnień paneli środnika stanowią krzyżulce a żebra poprzeczne pełnią funkcję słupków.

$q_{E d}$

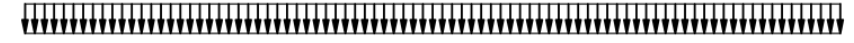

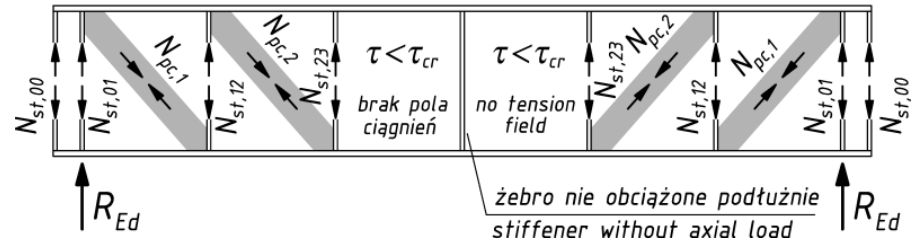

Rys. 3. Model statyczny blachownicy w stanie nadkrytycznym w postaci kratownicy Pratta, gdzie: $N_{p c, 1}, N_{p c, 2}$ - wypadkowe sił pól ciągnień; $N_{s t, 00}, N_{s t, 01}-$ siły podłużne w żebrach krańcowych i podporowych oraz $N_{s t, 12}, N_{s t, 23}$ - siły podłużne w żebrach pośrednich

Fig. 3. Static system of plate girder in post-bucking range at the form of Pratt's truss, where: $N_{p c, 1}$, $N_{p c, 2}$ - resultant forces of tension fields; $N_{s t, 00}, N_{s t, 01}$ - longitudinal forces at end and support stiffeners and $N_{s t, 12}, N_{s t, 23}$ - longitudinal forces at intermediate stiffeners

W nadkrytycznej fazie pracy żebra poprzeczne są elementami ściskanymi, które wraz z pasami blachownicy i rozciąganymi pasmami środnika zapewniają przeniesienie obciążeń poprzecznych na łożyska podporowe zapewniając niezmienność dystansu pomiędzy pasem ściskanym a rozciąganym, co warunkuje utrzymanie nośności przekroju na zginanie. 
Specjalną rolę pełnią, najsilniej obciążone, podporowe żebra skrajne, których zadaniem jest zapewnienie stateczności środnika przy ściskaniu wywołanym działaniem pionowej składowej przypodporowego pola ciągnień oraz przekazanie na tarcze pasów reakcji żebra zginanego na skutek działania poziomej składowej pola ciągnień.

Na skutek narastających odkształceń i częściowego uplastycznienia materiału w polu ciągnień przyrost obciążeń wywołuje tzw. ramowy mechanizm pracy blachownicy (rys. 1c), który jest ostatnią fazą poprzedzającą zniszczenie. Pasy zostają obciążone poprzecznie do swej płaszczyzny pionową składową pola ciągnień, przez co dochodzi do ich zginania w płaszczyźnie belki, a następnie do wytworzenia się w pasach „przegubów plastycznych”, które ostatecznie przekształcają ustrój w mechanizm, uniemożliwiając dalsze zwiększanie obciążenia.

Spośród licznych modeli opisujących zachowanie się blachownic w stanie nadkrytycznym bliżej przedstawione zostaną dwa wybrane modele obliczeniowe opisu mechanizmu pól ciągnień, które znalazły zastosowanie we współczesnych normach projektowania konstrukcji stalowych do wyznaczania sił wewnętrznych w pośrednich żebrach usztywniających.

\subsection{Model Cardiff (Rockeya-Škalouda)}

W początkowej fazie obciążenia, tzw. pracy belkowej złożono (por. [12]), że płyta środnika pozostaje idealnie płaska do chwili przekroczenia wartości krytycznych naprężeń stycznych

$$
\tau_{c r}=k_{b} \frac{\pi^{2} E}{12\left(1-v^{2}\right)}\left(\frac{t}{b}\right)^{2}
$$

gdzie: $k_{b}$ - współczynnik wyboczeniowy płyty ścinanej,

$$
k_{b}=\left\{\begin{array}{lll}
5,34+4\left(\frac{b}{a}\right)^{2} & \text { dla } & \frac{a}{b} \geq 1,0 \\
5,34\left(\frac{b}{a}\right)^{2}+4 & \text { dla } & \frac{a}{b}<1,0
\end{array},\right.
$$

$E$ - współczynnik sprężystości podłużnej,

$v$ - współczynnik Poissona,

$t$ - grubość środnika,

$b$ - wysokość płyty środnika,

$a$ - szerokość płyty środnika (rozstaw żeber). 


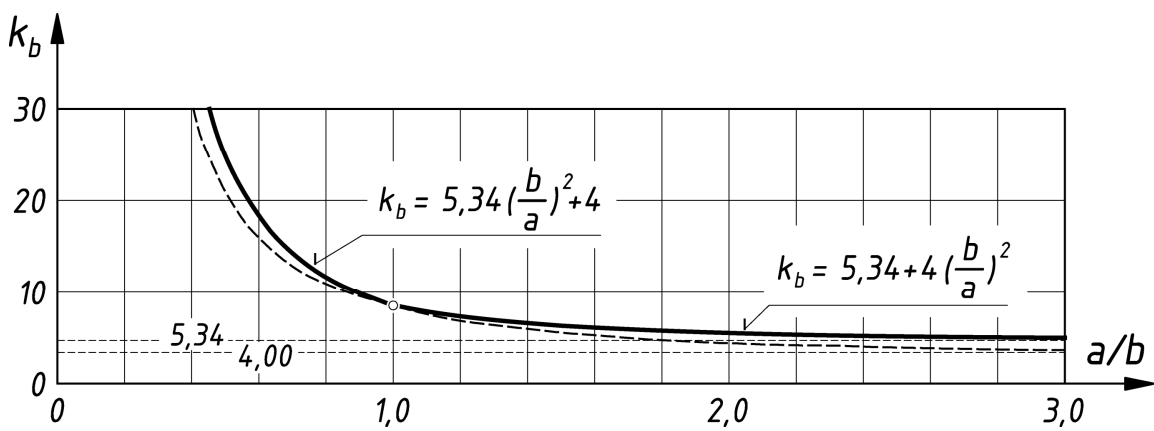

Rys. 4. Współczynnik wyboczeniowy płyty ścinanej $k_{b}$ w funkcji bezwymiarowego parametru geometrii płyty a/b

Fig. 4. Shear plate buckling coefficient $k_{b}$ as a function of dimensionless plate geometry parameter $a / b$

Po osiągnięciu przez naprężenia styczne wartości krytycznej następuje utrata stateczności płyty środnika i uformowanie się charakterystycznych wybrzuszeń wzdłuż przekątnej panelu środnika. W opisie pola naprężeń można wyróżnić pole ciągnień, które w opisywanym modelu obejmuje jedynie środkowe pasmo panelu. Przyjmuje się również, że pominięte zostanie działanie bocznych pól ciągnień, a ponadto $\mathrm{w}$ obrębie rozpatrywanego pasma środkowego rozkład naprężeń rozciągających jest równomierny (rys. 5).

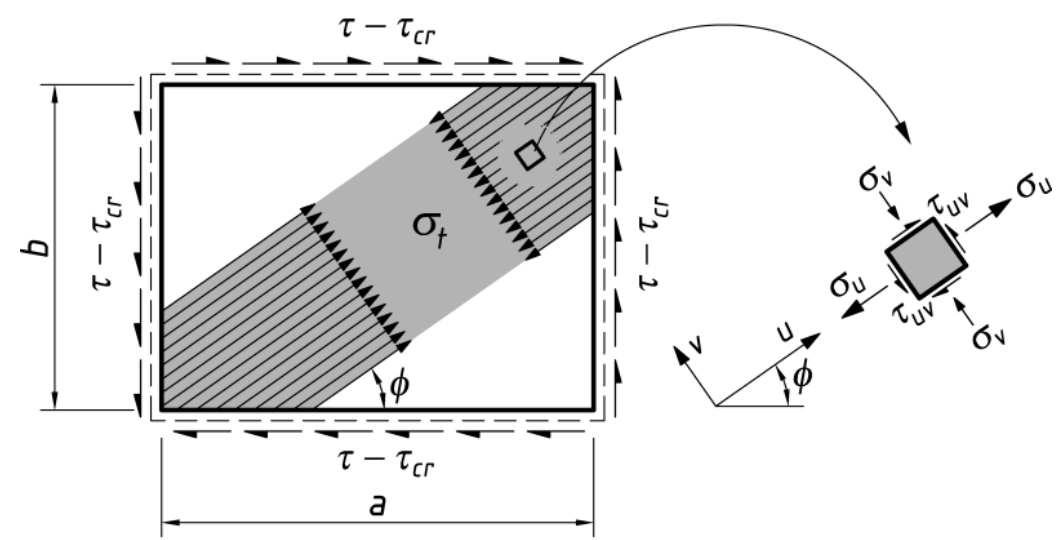

Rys. 5. Składowe stanu naprężeń pola ciągnień

Fig. 5. Stress state components of the tension field

Stan naprężeń w polu ciągnień najdogodniej jest opisać w kartezjańskim układzie współrzędnych $u v$ o osi odciętych zorientowanej zgodnie z kierunkiem osi podłużnej pola ciągnień (rys. 5) 


$$
\left\{\begin{array}{l}
\sigma_{u}=\sigma_{t}+\tau_{c r} \sin (2 \phi) \\
\sigma_{v}=-\tau_{c r} \sin (2 \phi) \\
\tau_{u v}=\tau_{c r} \cos (2 \phi)
\end{array} .\right.
$$

Strumienie naprężeń stycznych na brzegach panelu są równe „nadwyżce” jaką dają naprężenia obliczone na podstawie działających obciążeń zewnętrznych pomniejszone o krytyczne naprężenia styczne. W fazie pracy ramowej, poprzedzającej zniszczenie na skutek działania jednoczesnego rozciągania i ścinania, następuje częściowe uplastycznienie pasma rozciąganego, co skutkuje zwiększeniem obciążenia poprzecznego pasów i w konsekwencji wytworzeniem się w nich „przegubów plastycznych” w osiach żeber oraz na odcinku międzyżebrowym przekształcając układ konstrukcyjny w mechanizm.
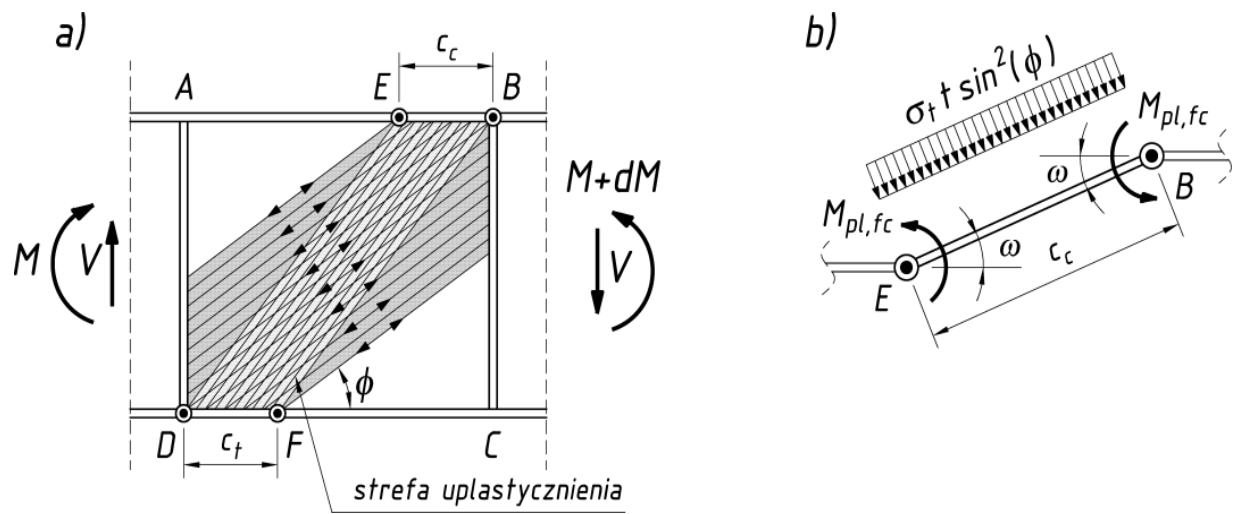

Rys 6. Mechanizm zniszczenia blachownicy w stanie nadkrytycznym według modelu Cardiff:

a) strefa uplastycznienia w środniku, b) model kinematyczny pasa ściskanego

Fig. 6. Failure mechanism of plate girder in post-buckling range according to Cardiff model:

a) web zone of plastification, b) kinematic model of compressed flange

Nośność panelu ścinanego $V_{u, C}$ można zatem zapisać jako sumę trzech składników

$$
V_{u, C}=V_{b}+V_{t f}+V_{f r},
$$

gdzie: $V_{b}$ - składnik wywołany pracą belkową (nośność dokrytyczna),

$V_{t f}-$ składnik wywołany pracą pola ciągnień,

$V_{f r}-$ składnik wywołany pracą ramową.

Korzystając z równań równowagi oraz kryterium plastyczności HuberaMisesa-Hencky'ego powyższą formułę nośności granicznej blachownicy ze względu na działanie siły poprzecznej można przedstawić w bardziej szczegółowej postaci 


$$
V_{u, C}=\tau_{c r} b t+\sigma_{t} t b \sin ^{2}(\varphi)\left(\operatorname{ctg}(\varphi)-\operatorname{ctg}(\theta)+\frac{c_{c}}{b}+\frac{c_{t}}{b}\right)+\left(\frac{2 M_{p l, f c}}{c_{c}}+\frac{2 M_{p l, f t}}{c_{t}}\right),
$$

gdzie: $c_{c}$ i $c_{t}$ - rozstaw przegubów plastycznych w pasie ściskanym i rozciąganym odpowiednio,

$\theta$ - kąt pochylenia przekątnej panelu, oraz

$M_{p l, f c}$ i $M_{p l, f t}$ momenty plastyczne w pasie ściskanym i rozciąganym odpowiednio.

Rozstawy $c_{c}$ i $c_{t}$ można wyznaczyć korzystając z zasady prac wirtualnych, rozpatrując model kinematyczny fragmentu pasa górnego wydzielonego przegubami plastycznymi (rys. 6b)

$$
\begin{aligned}
& c_{c}=\frac{2}{\sin (\varphi)} \sqrt{\frac{M_{p l, f c}}{\sigma_{t} t}}, \\
& c_{t}=\frac{2}{\sin (\varphi)} \sqrt{\frac{M_{p f t}}{\sigma_{t} t}} .
\end{aligned}
$$

Kąt pochylenia pola ciągnień $\varphi$ można wyznaczyć iteracyjnie, maksymalizując wartość $V_{s}$ albo przyjąć wartość przybliżoną

$$
\varphi=\frac{2}{3} \operatorname{arctg}(\theta)
$$

Zakładając, że momenty plastyczne w pasie górnym i dolnym są sobie równe oraz, że rozstawy przegubów plastycznych w pasie ściskanym i rozciąganym są takie same, tj. $c_{t}=c_{c}=c$, otrzymujemy

$$
V_{u, C}=\tau_{c r} b t+3 \sigma_{t, y} c t \sin ^{2}(\varphi)+\sigma_{t, y} b t \sin ^{2}(\varphi)(\operatorname{ctg}(\varphi)-\operatorname{ctg}(\theta))
$$

gdzie $\sigma_{t, y}$ to naprężenia normalne pola ciągnień $\mathrm{w}$ chwili uplastycznienia środnika.

Naprężenia te można wyznaczyć wykorzystując kryterium plastyczności Hubera-Misesa-Hencky’ego dla dwuosiowego stanu naprężeń oraz wzory (3)

$$
\sigma_{t, y}=\sqrt{f_{y w}{ }^{2}-\tau_{c r}^{2}\left(3-\left(\frac{3}{2} \sin (2 \phi)\right)^{2}\right)}-\frac{3}{2} \tau_{c r} \sin (2 \phi)
$$




\subsection{Model Stockholm (Höglunda)}

Model Stockholm, zwany też metodą obróconego pola naprężeń, został opracowany i był rozwijany przez Höglunda [6] od początku lat 70-tych ubiegłego wieku. Pierwotnie celem utworzenia modelu był opis zachowania się smukłych blachownic posiadających jedynie użebrowanie podporowe. W późniejszych pracach Höglund zmodyfikował model w sposób umożliwiający analizę blachownic z pośrednimi żebrami usztywniającymi. W przeciwieństwie do modelu Cardiff przyjęto, że w fazie pracy nadkrytycznej obszar niezerowych naprężeń pola ciągnień obejmuje całą szerokość panelu środnika. Założono również, że naprężenia główne ściskające są niezerowe i równe co do wartości krytycznym naprężeniom stycznym. Ze względu na dużą smukłość środnika $\mathrm{w}$ analizie pominięto naprężenia ściskające $\mathrm{w}$ kierunku prostopadłym do osi podłużnej blachownicy, co jest założeniem słusznym w przypadku blachownic nieużebrowanych o dużym rozstawie pomiędzy żebrami podporowymi. Przyjęto, że środnik składa się z wzajemnie krzyżujących się pod kątem prostym pasm rozciąganych i ściskanych (rys. 7).

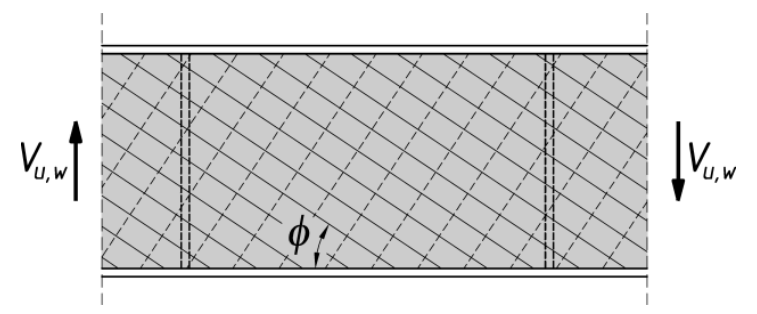

Rys. 7. Trajektorie naprężeń w panelu środnika poddanego działaniu sił poprzecznych według modelu Stockholm. Liniami ciągłymi oznaczono trajektorie naprężeń rozciągających, a przerywanymi ściskających

Fig. 7. Web panel stresses trajectory due to shear forces action according to Stockholm model. Tensional stresses trajectory was marked by continuous lines while compressional stresses by dashed lines

Po sprężystej utracie stateczności płyty środnika przy zwiększającym się obciążeniu naprężenia główne ściskające $\sigma_{2}$ nie mogą wzrastać. Z warunków równowagi trójkąta elementarnego (rys.8h) wynika, że wzrost obciążenia zewnętrznego, a w konsekwencji zwiększanie się wartości naprężeń stycznych $\tau$, w stanie nadkrytycznym może być równoważone jedynie naprężeniami $\sigma_{1}$. Przy czym, jeśli uwzględni się fakt, że w trakcie wzrostu obciążenia $\sigma_{2}=$ const. oraz kąt między trajektoriami naprężeń głównych jest stały i równy $90^{\circ}$, to stan równowagi przy kolejnych przyrostach obciążenia będzie zachodził przy stopniowo zmniejszającym się kącie $\phi$, który osiągnie wartość minimalną w fazie zniszczenia, co wyjaśnia wprowadzenie przez autora nazwy metoda obróconego pola naprężeń (rotated field method) - por. rys. 8 [7]. 


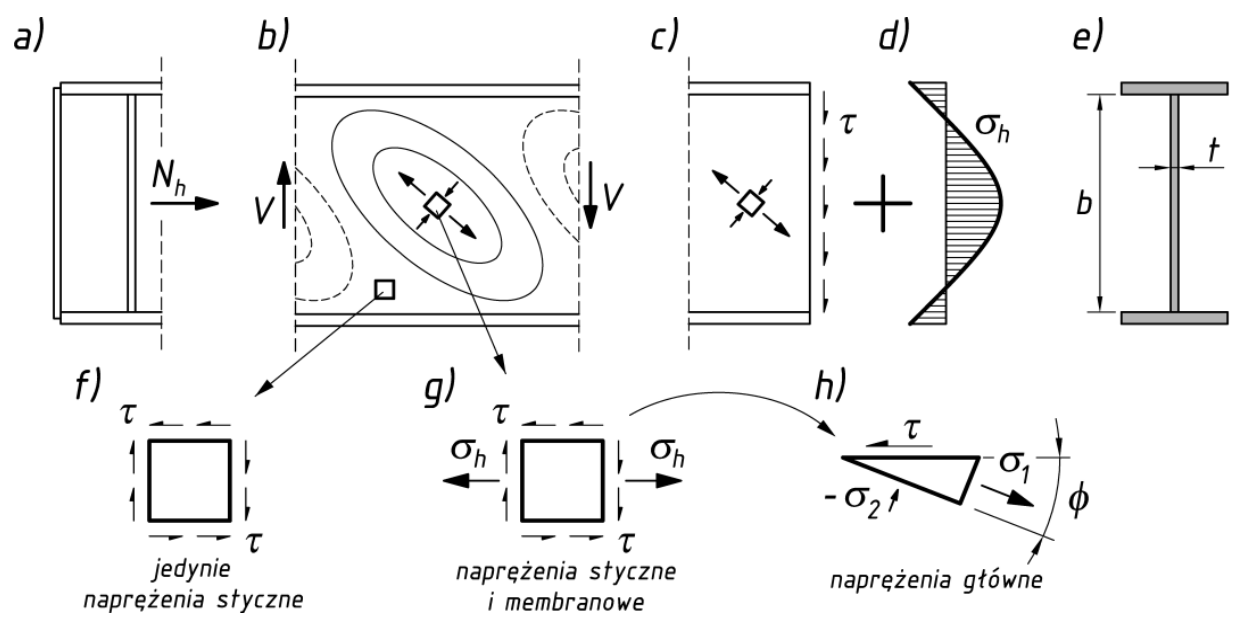

Rys 8. Stan naprężeń w nadkrytycznej fazie pracy blachownicy według modelu Stockholm

Fig. 8. Stress state of plate girder in post-buckling range according to Stockholm model

Rozpatrując opisany powyżej stan naprężeń w inżynierskim układzie osi współrzędnych związanych z kierunkiem wyznaczonym przez oś belki, można zauważyć, że stanowi on złożenie dwóch stanów naprężeń - ścinania (rys. 8c) oraz nierównomiernego rozciągania (rys. 8d), którego wypadkowa $N_{h}$ musi zostać przeniesiona poprzez zginanie żebra podporowego, wywołując dodatkowe ściskanie pasów. Biorąc pod uwagę równowagę trójkąta elementarnego (rys. 8h) naprężenia główne można wyrazić następująco

$$
\begin{aligned}
& \sigma_{1}=\frac{\tau}{\operatorname{tg} \phi}, \\
& \sigma_{2}=-\tau \cdot \operatorname{tg} \phi,
\end{aligned}
$$

przy czym membranowe naprężenia ściskające ograniczone są wartością naprężeń krytycznych

$$
\sigma_{2}=-\tau_{c r}
$$

Stosując kryterium plastyczności Hubera-Misesa-Hencky'ego oraz uwzględniając (1) i wprowadzając umowną smukłość względną płytową przy ścinaniu

$$
\bar{\lambda}_{w}=\sqrt{\frac{f_{y w} / \sqrt{3}}{\tau_{c r}}},
$$

znormalizowane naprężenia graniczne przy ścinaniu można przedstawić jako 


$$
\frac{\tau_{u}}{f_{y w} / \sqrt{3}}=\frac{1}{\bar{\lambda}_{w}^{2}} \sqrt{\sqrt{3 \bar{\lambda}_{w}^{4}-\frac{3}{4}}-\frac{1}{2}} .
$$

W przypadku dużych smukłości $\left(\bar{\lambda}_{w}>2,5\right)$ pierwiastek w powyższym wzorze przyjmuje wartość zbliżoną do jedności, co upraszcza formułę do postaci

$$
\frac{\tau_{u}}{f_{y w} / \sqrt{3}}=\frac{1,32}{\bar{\lambda}_{w}} .
$$

Ramowy mechanizm pracy blachownicy może wytworzyć się jedynie przy obecności poprzecznych żeber usztywniających (rys. 9). Przyjmując, że w obydwu ,przegubach plastycznych” mamy tą samą wartość momentu plastycznego, $\mathrm{z}$ warunku równowagi odcinka pasa o długości $c$ można wyznaczyć dodatkowy składnik nośności na siłę poprzeczną $V_{u, f}$, który powstaje dzięki pracy układu ramowego złożonego z pasów i żeber poprzecznych,

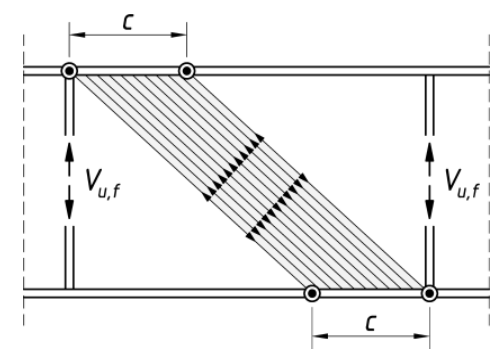

Rys. 9. Mechanizm pracy ramowej blachownicy wg modelu Stockholm

Fig. 9. Frame mechanism of plate girder work according to Stockholm model

$$
V_{u, f}=\frac{4 M_{f p}}{c}
$$

przy czym rozstaw przegubów plastycznych można wyznaczyć za pomocą formuły

$$
c=a\left(0,25+\frac{1,6 b_{f} t_{f}^{2} f_{y f}}{t b^{2} f_{y w}}\right) .
$$

Należy przy tym podkreślić, że $V_{u, f}$ jest zarazem składową nośności blachownicy na siłę poprzeczną oraz wypadkową strumienia naprężeń stycznych na krawędziach panelu blachownicy, które stanowią siłę obciążającą żebra poprzeczne. Nośność graniczną ścinanego panelu blachownicy poddanego działaniu naprężeń stycznych według modelu Stockholm można zatem zapisać w postaci sumy składowych pochodzących od nośności płyty środnika $V_{u, w}$ i nośności pochodzącej od uplastyczniania się pasów $V_{u, f}$ 


$$
V_{u, S}=V_{u, w}+V_{u, f} .
$$

Model Stockholm został zaimplementowany $\mathrm{w}$ obecnej wersji normy PN-EN 1993-1-5 [11], stanowiąc podstawę do wyznaczania nośności blachownic na siłę poprzeczną.

\section{Modele nośności żeber poprzecznych we współczesnych normach projektowania}

Współczesne normowe modele obliczeniowe żeber poprzecznych blachownic przedstawiane są $\mathrm{w}$ ujęciu metody stanów granicznych. W odniesieniu do pośrednich żeber poprzecznych, które pracowały jedynie w zakresie dokrytycznej pracy blachownicy, starsze generacje norm wymagały jedynie spełnienia warunku sztywności. W nowszych opracowaniach, ujmujących również nadkrytyczny zakres pracy blachownicy, warunki stawiane pośrednim żebrom poprzecznym obejmują zarówno stan graniczny użytkowalności, jak i nośności. W takim przypadku, ogólnie uznawanym modelem statycznym pośredniego żebra poprzecznego jest fikcyjny, wyizolowany z konstrukcji blachownicy, dwuprzegubowo podparty pręt ściskany i dwukierunkowo zginany o rozpiętości równej wysokości płyty środnika; przy czym żebra pośrednie, w przeciwienstwie do żeber podporowych, najczęściej zginane są jedynie w płaszczyźnie prostopadłej do powierzchni środkowej środnika

Przy zapewnieniu poprzecznej nieprzesuwności w miejscu przyłożenia obciążenia zewnętrznego do żebra pośredniego, jego długość wyboczeniową można przyjmować równą $75 \%[4,11]$ albo $80 \%$ wysokości środnika [10]. Gdy żebro pośrednie jest nieobciążone zewnętrzną siła skupioną i niepodparte stężeniem bocznym, lecz blachownica oraz jej przekrój poprzeczny spełniają warunki stanu granicznego nośności i użytkowalności, to długość wyboczeniową żebra można przyjmować równą wysokości płyty środnika.

Podstawą konstrukcji normowych modeli obliczeniowych oraz warunków nośności i sztywności żeber pośrednich są teorie stateczności sprężystej płyt użebrowanych lub opisane wcześniej modele stanów granicznych pól ciągnień, które są uzupełniane o składniki pominięte $\mathrm{w}$ analizie $\mathrm{z}$ tytułu idealizacji, niezbędnej przy tworzeniu fizycznego lub matematycznego modelu żebra. Najliczniejszą grupę uzupełnień stanowią elementy modelu obciążeń, przy czym w grupie tej można wydzielić czynniki stanowiące źródła sił podłużnych oraz momentów zginających żebro. Siły podłużne w żebrze pośrednim są przede wszystkim efektem działania pola ciągnień w przyległych panelach środnika oraz ewentualnych sił skupionych bezpośrednio do niego przyłożonych. Pod uwagę należy również brać dodatkowe siły wynikające z działania wypadkowej sił ściskających pas dźwigara o osi krzywoliniowej albo załamanej (rys. 10). 
a)

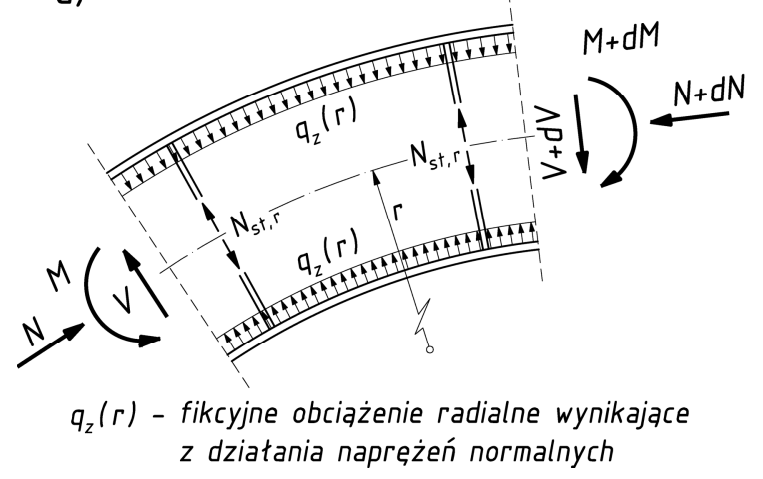

b)

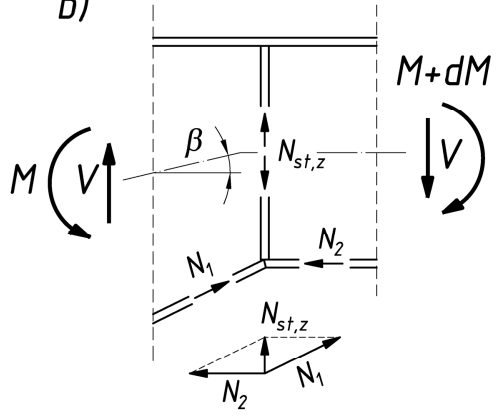

Rys. 10. Obciążenie żeber pośrednich dźwigarów o osi: a) krzywoliniowej i b) załamanej

Fig. 10. Loads of intermediate plate girder stiffeners with: a) curvilinear axis and b) bent axis

W najbardziej ogólnym przypadku, przy dużych smukłościach środnika, żebro pośrednie może być dwukierunkowo zginanie. Źródłem momentów zginających żebro pośrednie w płaszczyźnie prostopadłej do osi blachownicy może być: mimośrodowość przekroju żebra jednostronnego, mimośrodowość przyłożenia zewnętrznych sił skupionych, oddziaływanie naprężeń normalnych w przyległych panelach środnika na mimośrodzie wywołanym wygięciem wstępnym żebra, siła reakcji współpracujących żeber podłużnych oraz współdziałanie żebra w poprzecznym układzie nośnym, np. w mostach dwudźwigarowych z jezdnią dolną. Momenty zginające żebro pośrednie w płaszczyźnie środnika mogą zostać wywołane mimośrodem przyłożenia zewnętrznej siły skupionej.

Wprowadzenie do procedury obliczeniowej żebra pośredniego modelu pręta ściskanego $\mathrm{z}$ imperfekcją $\mathrm{w}$ postaci wygięcia wstępnego oraz ewentualnym dodatkowym obciążeniem poprzecznym siłami skupionymi stanowiącymi reakcje żeber podłużnych implikowało konieczność zastosowania analizy sprężystej II-ego rzędu oraz weryfikacji przekroju żebra zarówno ze względu na stan graniczny nośności, jak i użytkowalności

$$
\begin{aligned}
& \sigma_{z, \max } \leq \frac{f_{y}}{\gamma_{M}}, \\
& u_{y, \max } \leq u_{d o p}=b / 300 .
\end{aligned}
$$

Przyjęty w normie [11] model fizyczny żebra pośredniego stanowi układ statyczny, w którym oś wstępnie wygiętego żebra jest linią o kształcie półfali sinusoidy o strzałce $w_{0}$ na styku dwóch przyległych wybrzuszonych paneli środnika, które modelowane są powłokami prostokreślnymi (rys. 11). 


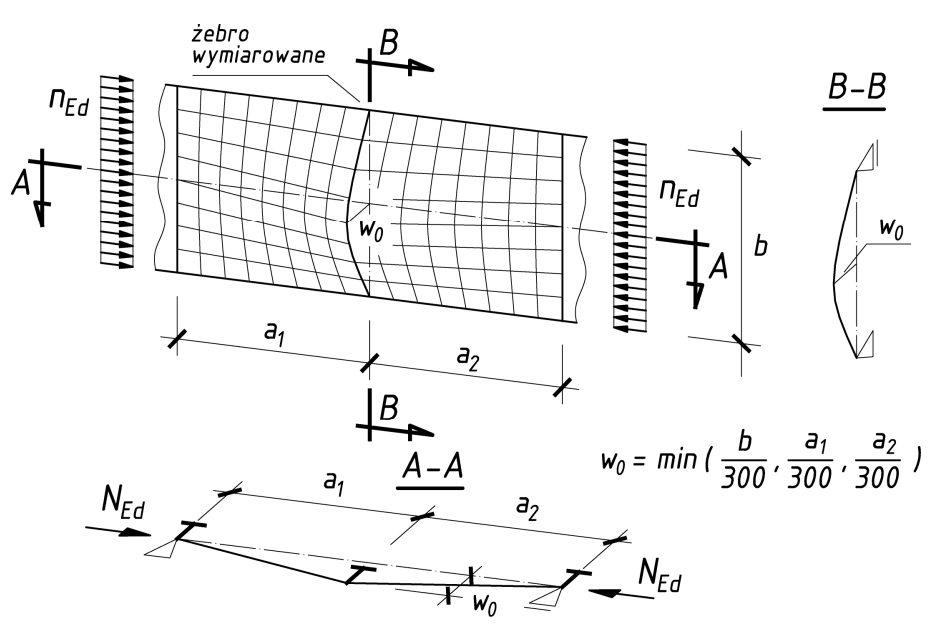

Rys. 11. Schemat statyczny żebra pośredniego blachownicy według PN-EN 1993-1-5 [11]

Fig. 11. Static system of intermediate plate girder stiffeners according to PN-EN 1993-1-5 [11]

W linii styku nie jest spełniony warunek ciągłości pochodnej geometrycznego równania powłoki, co powoduje, że przy równomiernym ściskaniu paneli składowe naprężeń normalnych prostopadłe do powierzchni środnika stanowią dla żebra pośredniego obciążenie poprzeczne o nierównomiernym rozkładzie sinusoidalnym, które można wyprowadzić z warunku równowagi sił w linii styku paneli.

$$
q^{\prime}(z)=w(z) \frac{\sigma_{c r, c}}{\sigma_{c r, p}}\left[\left(\frac{1}{a_{1}}+\frac{1}{a_{2}}\right) \frac{N_{E d}}{b}\right]=w(z) \sigma_{m}
$$

gdzie: $w(z)$ - funkcja ugięcia osi żebra,

$\sigma_{c r, c}-$ krytyczne naprężenia normalne prętowej formy utraty stateczności,

$$
\sigma_{c r, c}=\frac{\pi^{2} E t^{2}}{12\left(1-v^{2}\right) a^{2}}
$$

$\sigma_{c r, p}-$ krytyczne naprężenia normalne płytowej formy utraty stateczności

$$
\sigma_{c r, p}=k_{\sigma, p} \frac{\pi^{2} E t^{2}}{12\left(1-v^{2}\right) b^{2}}
$$

Wprowadzone dodatkowo $\mathrm{w}$ powyższej formule wyrażenie ułamkowe $\sigma_{c r, c} \sigma_{c r, p}$ jest w swej istocie współczynnikiem redukcyjnym, który ujmuje korzystny wpływ sztywności giętnej płyty środnika w kierunku prostopadłym do osi blachownicy. W celu uproszczenia obliczeń zgodnie z [11] dopuszcza się prowadzenie analizy statycznej według teorii pierwszego rzędu, lecz tylko wtedy, gdy żebro nie jest obciążone siłą podłużną, przy czym obciążenie $q^{\prime}(z)$ 
o należy wtedy zastępować obciążeniem ekwiwalentnym $q(z)$ o rozkładzie równomiernym

$$
q(z)=\frac{\pi}{4}\left(w_{0}(z)+w_{e l}(z)\right) \sigma_{m} .
$$

Jeśli w żebrze pośrednim nie występuje siła podłużna, a ponadto nie jest ono obciążone poprzecznie reakcjami żeber podłużnych lub innymi obciążeniami, to prostszym sposobem wymiarowania jest spełnienie warunku sztywności

$$
I_{s t} \geq I_{s t, \min }
$$

gdzie,

$$
I_{s t, \text { min }}=\frac{\sigma_{m}}{E}\left(\frac{b}{\pi}\right)^{4}\left(1+w_{0} \frac{300}{b} u\right),
$$

przy czym

$$
u=\frac{\pi^{2} E e_{\max }}{\frac{f_{y} 300 b}{\gamma_{M 1}}} \geq 1,0
$$

gdzie: $\sigma_{m}$ - por. wzór (22),

$e_{\max }-$ maksymalna odległość skrajnego włókna żebra od jego środka ciężkości,

$f_{y}$ - granica plastyczności żebra,

$\gamma_{M 1}$ - współczynnik częściowy przy sprawdzaniu stateczności.

W przypadku, gdy żebro jest obciążone siłą podłużną wynikającą z działania pól ciągnień lub obciążenia zewnętrzną siłą skupioną oraz ewentualnym momentem zginającym wynikającym $\mathrm{z}$ asymetrii przekroju żebra poprzecznego, analizę statyczną należy prowadzić wg teorii II-ego rzędu; przy czym obliczenia można wykonać w sposób uproszczony, stosując metodę amplifikacji. W podejściu tym działanie obciążenia $q^{\prime}(z)$ można zastąpić dodatkową fikcyjną siłą podłużną

$$
\Delta N_{s t}=\frac{\sigma_{m} b^{2}}{\pi^{2}},
$$

która stanowi czynnik zwiększający wartość ugięć oraz momentów zginających lecz nie powoduje zwiększenia wartości siły osiowej w żebrze.

Gdy źródłem momentów zginających żebro nie jest asymetria jego przekroju, to należy przeprowadzić analizę statyczną II-ego rzędu przyjmując obciążenie poprzeczne równomiernie rozłożone $q(z)$. 
Siłę podłużną $N_{s t}$, powstającą w żebrze pośrednim na skutek działania pól ciągnień, należy zgodnie z normą [11] przyjmować jako różnicę pomiędzy wartością siły poprzecznej w osi żebra $V_{E d}$ a nośnością środnika na siłę poprzeczną w stanie dokrytycznym

$$
N_{s t}=V_{E d}-\tau_{c r} b t=V_{E d}-\frac{1}{\bar{\lambda}_{w}^{2}} b t \frac{f_{y}}{\sqrt{3} \gamma_{M 1}} .
$$

Należy tutaj zwrócić uwagę na to, że normowy sposób wyznaczania sił osiowych $\mathrm{w}$ żebrach podłużnych jest wewnętrznie niespójny z przyjętym modelem opisu pola ciągnień. Formułę (30) wyprowadzono na podstawie modelu Cardiff, podczas gdy nośność przekroju na siłę poprzeczną zgodnie z [11] zaleca się przyjmować według modelu Stockholm.

Warunki normowe nośności i sztywności pośredniego żebra poprzecznego sformułowano na podstawie opisu zachowania się ściskanego i zginanego pręta płaskiego. Zabezpieczenie przed wystąpieniem przestrzennych form utraty stateczności żebra można uzyskać jeżeli spełnione zostaną dodatkowe warunki sztywności przekroju poprzecznego żeber. W przypadku, gdy profil żebra charakteryzuje się zerową wartością wycinkowego momentu bezwładności, warunek stateczności skrętnej żebra ma postać

$$
\frac{I_{T}}{I_{P}} \geq 5,3 \frac{f y}{E},
$$

gdzie: $I_{P}$ - biegunowy moment bezwładności przekroju żebra względem punktu styczności ze ścianką środnika,

$I_{T}$ - moment bezwładności przekroju żebra przy skręcaniu swobodnym.

Najczęściej stosowanym przekrojem zastępczym żeber pośrednich jest przekrój krzyżowy. Taka forma przekroju poprzecznego charakteryzuje się zerową wartością wycinkowego momentu bezwładności, czego konsekwencją jest brak wpływu rozpiętości żebra na wartość siły krytycznej wyboczenia skrętnego. Przy stosunkowo niedużych rozpiętościach żeber zwiększanie pola przekroju płaskowników żeber w celu spełnienia warunku stateczności skrętnej nie ma wtedy uzasadnienia. Racjonalnym rozwiązaniem powyższego problemu jest wykorzystanie przekrojów o niezerowej sztywności deplanacyjnej. Zwykle są to profile kątowe albo teowe, rzadziej profile zamknięte. Warunek stateczności skrętnej żeber tego rodzaju należy przyjmować w postaci

$$
\sigma_{c r, T} \geq 6 f_{y},
$$

przy czym $\sigma_{c r, T}$ - sprężyste naprężenia krytyczne przy wyboczeniu skrętnym żebra należy wyznaczać jak dla przekroju izolowanego, tj. z pominięciem sztywności przyległych paneli środnika. 


\section{Podsumowanie i uwagi krytyczne}

Wykorzystanie w jak największym stopniu nadkrytycznej rezerwy nośności blachownic stalowych wymaga wykorzystania współpracy panelu środnika $\mathrm{z}$ żebrami poprzecznymi. Redystrybucja naprężeń przekrojowych w stanie nadkrytycznym jest przyczyną występowania jakościowo odmiennej formy zniszczenia blachownicy, w której istotną rolę odgrywa interakcja elementów składowych blachownicy, nie tylko pasów i środnika lecz również żeber poprzecznych. W tym przypadku, prawidłowy opis mechaniki zniszczenia, wykracza poza granice stosowania klasycznych modeli prętowych. Sformułowanie warunków równowagi w stanie granicznym nośności jest możliwe przy uwzględnieniu plastycznych właściwości stali oraz równoważeniu naprężeń i sił wewnętrznych, nie w obrębie płaskiego przekroju poprzecznego lecz w obrębie sekcji blachownicy ograniczonej sąsiednimi żebrami poprzecznymi. Żebra poprzeczne blachownic $\mathrm{w}$ stanie nadkrytycznym wymiarowane są zarówno ze względu na warunek sztywności, jak i warunek nośności. Nawet przy braku zewnętrznych obciążeń skupionych żebro poprzeczne jest poddane działaniu siły podłużnej pochodzącej od działania pól ciągnień. Ze względu na to, że żebra poprzeczne powinny być dodatkowo zdolne do przeniesienia zginania wynikającego z wstępnego wygięcia swej osi oraz ewentualnej mimośrodowości przekroju oraz oddziaływania reakcji żeber podłużnych, analizę statyczną żebra należy, zgodnie z obowiązującą normą PN-EN 1993-1-5 [11], prowadzić wedhug teorii II-ego rzędu. Przepis ten $w$ istotnym stopniu komplikuje proces wymiarowania żeber poprzecznych oraz budzi wątpliwości co do zasadności jego wprowadzenia, zwłaszcza przypadku stosowania blachownic w szkieletach nośnych obiektów kubaturowych w których, poza obecnie stosunkowo nielicznymi realizacjami ciężkich konstrukcji przemysłowych, wysokość przekroju blachownicowego rzadko przekracza $2,0 \mathrm{~m}$.

Normowy [11] model obciążenia żeber pośrednich jest niespójny z modelem nośności blachownicy na siłę poprzeczną. Obciążenia żeber pośrednich zaleca się wyznaczać są według modelu Cardiff, podczas gdy nośność na siłę poprzeczną należy obliczać na podstawie modelu Stockholm. Wartość siły podłużnej w żebrze pośrednim jest integralnym elementem zastosowanej teorii pola ciągnień, dlatego otrzymane wartości liczbowe obciążeń mogą znacznie się od siebie różnić. Wyznaczanie obciążeń żeber zgodnie z zaleceniami normy [11] może prowadzić do znacznego (nawet kilkukrotnego) przeszacowania ich wartości co eksperymentalnie potwierdzili Sinur i Beg [15].

Rozpatrując kwestię wyznaczania obciążeń wg [11] należy ponadto zwrócić uwagę na jeszcze jedną niekonsekwencję. Obciążenia wyznaczane według normowej formuly (30) określa się, przyjmując naprężenia krytyczne dla panelu środnika traktowanego jak przegubowo podparta na obwodzie płyta obciążona strumieniem naprężeń stycznych na swym obwodzie. W rzeczywistych blachownicach źródłem powstawania naprężeń stycznych jest gradient momentu 
zginającego, zatem naprężenia krytyczne płyty środnika powinny być wyznaczane dla modelu płyty obciążonej naprężeniami stycznymi i normalnymi pochodzącymi od działania momentu zginającego. Niestety, uwzględnienie w obecnej formule normowej powyższej uwagi zwiększyłoby, i tak już przeszacowaną, wartość siły podłużnej w żebrze poprzecznym.

\section{Literatura}

[1] Basler K.: Strength of plate girders in shear, ASCE Journal of the Structural Division, 87 (ST 7 Part 1), 1961, s. 151-180.

[2] Basler K.: Strength of plate girders under combined bending and shear, ASCE Journal of the Structural Division, 87 (ST 7 Part 2), 1961, s. 181-197.

[3] Basler K., Thürlimann B.: Strength of Plate Girders in Bending, ASCE Journal of the Structural Division, 87 (ST 6), 1961, s. 153-181.

[4] DASt - Richtlinie 015: Träger mit schlanken Stegen, Deutscher Ausschuß für Stahlbau, Stahlbau-Verlagsgesellschaft, Köln, 1990.

[5] Galambos T. V.: Guide to Stability Design Criteria for Metal, 4th Edition, John Wiley \& Sons, New York, 1988.

[6] Höglund T.: Shear buckling resistance of steel and aluminium plate girders, ThinWalled Structures, Vol. 29, No. 1-4, 1997, pp. 13-30.

[7] Johansson B., Maqoui R., Sedlacek G., Müller C., D. Beg: Commentary and worked examples to EN 1993-1-5 "Plated Structural Elements", First Edition, JRC-ECCS, Luxembourg, 2007.

[8] Kurrer K.-E.: The History of the Theory of Structures: From Arch Analysis to Computational Mechanics, Ernst \& Sohn, Berlin, 2008.

[9] Piekarczyk M.: Zginane stalowe dźwigary skrzynkowe w stanie pracy nadkrytycznej, Praca doktorska, Politechnika Krakowska, Kraków, 1991.

[10] PN-90/B-03200: Konstrukcje Stalowe. Obliczenia statyczne i projektowanie, Wydawnictwa Normalizacyjne Alfa-Wero Sp. z o.o., Warszawa, 1995.

[11] PN-EN 1993-1-5: Eurokod 3. Projektowanie konstrukcji stalowych. Część 1-5: Blachownice, PKN, Warszawa, 2008.

[12] Rockey K. C., Škaloud M.: The ultimate load behaviour of plate girders loaded in shear, The Structural Engineer, Vol. 50, Issue 1, 1972, pp. 29-47.

[13] Siepak J. S.: Nośność blachownic w stanach nadkrytycznych, Wydawnictwo Politechniki Krakowskiej, Kraków, 1983.

[14] Siepak J. S., Piekarczyk M., Wymiarowanie w stanie nadkrytycznym blachownic bisymetrycznych użebrowanych poprzecznie, Inżynieria i Budownictwo, $\mathrm{nr}$ 12, 1997, s.628-630.

[15] Sinur F., Beg D., (2012), Intermediate transverse stiffeners in plate girders, Steel Construction, Vol. 5, Issue 1, 2012, pp. 23-32. 


\title{
DESIGN MODELS OF GIRDERS INTERMEDIATE STIFFENERS
} IN POST-BUCKLING RANGE

\author{
S u m m a r y \\ Fundamental post-buckling theories of steel plate girders applied in contemporary design \\ codes were presented in this paper. Complex procedure of girder intermediate stiffener design \\ included in PN-EN 1993-1-5 [11] was described in respect to fundamental post-buckling theories. \\ Some inconsistency in code provisions, which could be reason of significant, even several times \\ [15], overestimation of stiffener longitudinal force values which is acting at post-buckling state \\ of plate girder work, were pointed out.
}

Keywords: transversal intermediate stiffeners, post-buckling reserve of strength, shear web stability

Przestano do redakcji:5.09.2014

Przyjęto do druku:1.12.2015

DOI: $10.7862 / \mathrm{rb} .2015 .153$ 